Lizentiatsarbeit der Philosophischen Fakultät

der Universität Zürich

Jürg Graf

\title{
Water Disinfection and Hygiene Behaviour in an Urban Slum in Kenya: \\ Impact on Childhood Diarrhoea and Influence of Beliefs
}

August 2007

Psychologisches Institut der Universität Zürich

Sozialpsychologie Prof. Dr. Heinz Gutscher

Referent \& Betreuung: Prof. Dr. Hans-Joachim Mosler 


\section{VORWORT}

Die vorliegende Lizentiatsarbeit entstand aus einer Kooperation zwischen der Fachrichtung Sozialpsychologie (Prof. Gutscher) am Psychologischen Institut der Universität Zürich und der Abteilung für Wasser und Siedlungshygiene in Entwicklungsländern (SANDEC) am Wasserforschungsinstitut (EAWAG) der Eidgenössischen Technischen Hochschule. Da die Absicht besteht, die Arbeit in einer Fachzeitschrift zu veröffentlichen, ist sie in Englisch verfasst. Ich möchte die Gelegenheit nutzen, einen herzlichen Dank an alle Personen auszusprechen, die beim erfolgreichen Gelingen der Lizentiatsarbeit beteiligt waren. Insbesondere den Mitarbeitenden der Kenianischen Nichtregierungsorganisation KWAHO für die gemeinsame Durchführung der Felderhebung in Nairobi, zudem Martin Wegelin und Regula Meierhofer von SANDEC, die das ganze Projekt initiiert und ermöglicht haben. Als ich in Kenia im Einsatz war, sind sie mir von der Schweiz aus immer mit Rat zur Seite gestanden. Mein weiterer Dank gilt natürlich Prof. Hans-Joachim Mosler von der EAWAG für die Betreuung der Lizentiatsarbeit und Unterstützung im Feld. Des Weiteren möchte ich Gabriela Landolt für das Korrekturlesen danken. Ein ganz „dickes“ Dankeschön gebührt im privaten Umfeld schliesslich Miriam Frischknecht, derer steter Rückhalt mir in allen Phasen des Projektes Kraft gab, und meinen Eltern, die mir ein Studium überhaupt ermöglichten. 


\begin{abstract}
Diarrhoea is one of the major causes of childhood death in developing countries. In this research project, we studied factors that presumably affect the incidence of diarrhoea among young children in urban slums: consumption of safe drinks, hygiene behaviour, cleanliness of household surroundings and the quality of raw water. Beliefs concerning the causes of diarrhoea were also related to health-improving behaviour, namely the application of the water-treatment method SODIS (solar water disinfection) and hygiene behaviour. We conducted a survey in Kibera, a huge shantytown in Nairobi, Kenya. Field workers interviewed a random sample of 500 households. Analysis with regression models revealed that two out of the four postulated factors (mentioned above) were significant: children have a lower risk of contracting diarrhoea when they consume high percentages of safe drinks and live in households with good hygiene behaviour. As regards beliefs, we found that biomedical knowledge of children's diarrhoea as well as the perceived social norm for treating water are associated with the use of SODIS and good hygiene behaviour. These findings underline the importance of water treatment at household level and safe hygiene practices for protecting the health of young children growing up in urban slum settlements. Our data suggest that these measures are more important for diarrhoea prevention than efforts focussing on cleaning up neighbourhoods.
\end{abstract}

\title{
Keywords
}

Solar water disinfection, safe drinking water, hygiene, diarrhoea, health behaviour 


\section{TABLE OF CONTENTS}

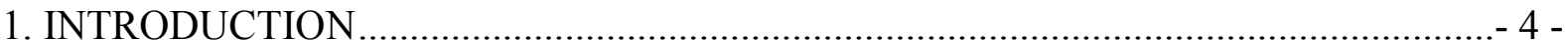

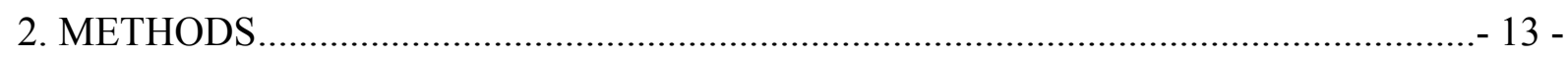

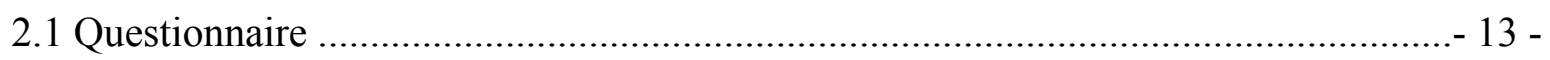

2.1.1 Incidence of diarrhoea .....................................................................................- 14 -

2.1.2 Consumption of drinks ...................................................................................- 14 -

2.1.3 Hygiene behaviour ………………………………………………………....- 15 -

2.1.4 Cleanliness of the household surroundings ........................................................- 16 -

2.1.5 Testing raw water quality …………………………………………………....- 17 -

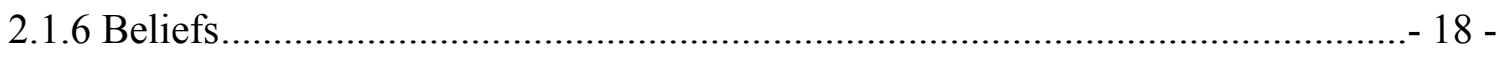

2.2 Course of the study ........................................................................................ 21 -

2.3 Description of the questioned sample ………………….........................................- 23 -

3. RESULTS

3.1 Factors influencing cases of diarrhoea among young children ...................................-27 -

3.2 The relationship between beliefs and the use of SODIS ........................................... 29 -

3.3 The relationship between beliefs and hygiene behaviour ...........................................- 30 -

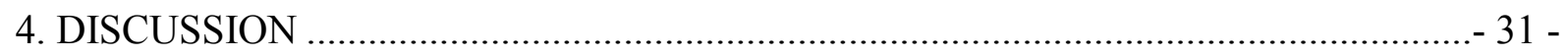

4.1 Limitations and further directions .......................................................................... 33 -

4.2 Practical implications ............................................................................................. 35 -

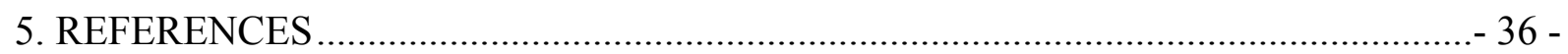

6. ANNEX: QUESTIONNAIRE.................................................................................. 39 - 


\section{INTRODUCTION}

In the less developed countries, 4,000 young children still die every day from the consequences of diarrhoeal diseases. And yet this suffering is largely preventable in view of the estimate by the World Health Organisation (WHO, 2005) that $88 \%$ of all diarrhoea cases are caused by unsafe water supplies, inadequate sanitation and insufficient hygiene practices. In its struggle against these shortcomings, the United Nations included a specific objective in its Millennium Development Goals: by the year 2015, the percentage of people without sustainable access to safe water and basic sanitation should be reduced by half (MDG 7, Target 10).

The water-treatment method known as SODIS (Solar water disinfection) can contribute to achieving this goal. SODIS only needs locally available resources such as sunlight and plastic bottles to treat drinking water at household level. Pathogens that could cause diarrhoea are destroyed if SODIS is used properly.

It works in the following way: water that could contain bacteria and viruses is poured into polyethylene terephtalat (PET) bottles and then exposed to direct sunlight for a minimum of six hours. The rooftops of buildings often represent a good place for such exposure. The UVA radiation and slight heating will kill the germs in the water. If the weather is very cloudy, the exposure time should be extended to two days (Meierhofer \& Wegelin, 2002). Overall, SODIS is a low-cost and simple addition to the usual ways of treating water (e.g. boiling, chlorination). It is therefore a particularly suitable way for the poorest segments of the population in the developing countries to obtain safe water with a modest use of resources.

Studies carried out on several continents in recent years showed the reducing effect of SODIS on the incidence of diarrhoea among children below five years in the field. In rural Kenya, the first controlled field trials were run with promising results (Conroy et al., 1996, 1999 \& 
2001). In his research in the Bolivian countryside, Hobbins (2003) found that the consumption of SODIS water decreased cases of diarrhoea among young children by $40 \%$. Rose et al. (2006) obtained exactly the same reduction rate in their health impact study in an urban slum in southern India.

Most recent studies did not focus primarily on the effectiveness of SODIS for the health of the users in the field, but rather on the social factors that are important in its diffusion and application. Altherr et al. (2006) found in their research in Nicaragua that the utilization of SODIS by households was linked to an overall positive attitude towards this technique. The intention to apply SODIS in the future was also linked to the use of SODIS by neighbours, and its actual use was related to knowledge about SODIS. In another research project run in Bolivia, Heri \& Mosler (submitted paper) studied the factors supporting the diffusion of SODIS.

Compared to other water-treatment methods (such as chlorination and boiling), relatively few studies have focussed on the health impact of SODIS in the field. The store of knowledge about this relatively new and promising method of water disinfection needs to be extended. The present paper is a contribution to countering this research deficit.

The aim of this study is to simultaneously evaluate the significance of the various factors that cause or prevent diarrhoea among young children in an urban slum. Water disinfection by SODIS is one of these factors, as will be seen later. Moreover, this research project also aimed at obtaining a better understanding of how the beliefs of the local inhabitants about the causes of childhood diarrhoea are related to health-improving behaviour, specifically to the use of SODIS and general hygiene behaviour.

The slum location that we chose to study was Kibera, the largest shantytown in the Kenyan capital of Nairobi. Because of its enormous population density, Kibera is said to be one of the largest slums in Sub-Saharan Africa. Around 700,000 people live on an area of almost 250 
hectares (HDR, 2006, p. 38). Since there is no real infrastructure in the slum, the living conditions are very tough. The situation in Kibera is similar to many other places in Africa and certainly to other shantytowns around the world. We will present a short description of this slum in Nairobi in order to illustrate what life can be like in an overpopulated urban settlement that lacks any public infrastructure and services.

Kibera has no official collection and disposal of garbage and waste water. The vast majority of households lack their own toilet and rely on a limited number of public on-site latrines that have to be shared with the neighbourhood. Thus, a single latrine is sometimes used by up to 150 people (Bongi \& Morel, 2005). Because of that, people also use plastic bags for their excrement, especially at night time when they don't want to leave home for security reasons. The next morning, the "flying toilet" - as this custom is called - is then thrown into the open drain, behind the next corner of the building or on a pile of rubbish on the street (HDR, 2006, p. 38). To get water for daily use, the residents have to go to water kiosks, where it is sold. Because the water is brought into the slums in several ways, often illegally, the price is higher than in the upper-class districts of Nairobi (WSP, 2005a). At the same time, the water is of dubious quality and shortages are frequent.

Since space in the slum is very limited, the huts, which are mostly constructed of dried mud, wood and corrugated iron, are built very near to each other. Typically, a family shares one room. It is estimated that on average 3.4 people have to live together within a space of around ten square meters (WSP, 2005b). The vast majority of the inhabitants of Kibera live below the poverty line and have to get by on less than one US-dollar per day. In short, the living conditions are very hard. The slum is extremely polluted; the paths, open areas and backyards are sometimes covered with faeces and rubbish. Open drains are often clogged with garbage so that the waste water can not flow away. Flies and mosquitoes are everywhere. Children growing up in such surroundings are constantly exposed to health hazards. 
One of the consequences for children who live in an overcrowded urban environment like Kibera are diarrhoeal diseases. Studies (APHRC, 2002) show that the prevalence of diarrhoea among children below the age of three is around $40 \%$ in Kibera, whereas it is much lower in Nairobi as a whole (13\%) and at national level in Kenya (17\%).

In the fight against diarrhoea, several different strategies are generally used in development projects: the provision of sanitary facilities, health and hygiene education programs, improvement of water supplies and water quality. They all aim to prevent the transmission of faecal pathogens, referring to the 'F-scheme' of Wagner \& Lanoix (1958). This scheme describes the routes that faecal bacteria can take through the environment to reach new hosts. Normally, the bacteria in stools die after being excreted. However, some can get onto the fingers, into food or water and may reach new human organisms. If excreta are not disposed of safely, they may be carried by flies, other animals and human feet so that pathogens are brought into the domestic environment, where food and cooking utensils can be contaminated. Children may also play with or eat soil infected with faeces. And water which was contaminated by faecal material may be drunk or used to prepare food. So there are several transmission routes for such contamination, and the purpose of these various strategies or interventions is to block them.

Fewtrell et al. (2005) systematically compared a number of studies that investigated the effectiveness of specific interventions on the incidence of diarrhoea among young children. A total of 46 studies that met the methodological quality standards were selected. The data was included in a meta-analysis in order to estimate the effectiveness of each type of intervention: sanitation, hygiene, water supply and water quality. They found that all these interventions had a significant reducing effect on the prevalence of diarrhoea among children. The degree of impact was similar for all of them, and none of them stuck out from the group. A rather surprising outcome was that projects implementing multiple interventions did not prove to be 
more effective than those based on a single intervention. Moreover, the authors highlight the fact that water-quality interventions that focussed on the treatment of water at the point of use (local household source) had a better impact than that found in previous reviews. For Fewtrell et al. (2005), this result makes sense, because "many households in less developed countries do not have individual connections to treated, piped water, or $24 \mathrm{~h}$ access to water. Such households typically store water in the home, and this water is vulnerable to contamination (primarily from handling) during transport and storage, even if it is clean at source" (p.47/8). These findings therefore support the significance of domestic methods of water treatment such as SODIS.

One purpose of the present study was to investigate the effect of using SODIS on the health of young children in an urban slum setting. However, taking into account the described Fscheme, we wanted to consider not only water quality as an explanatory factor for children's diarrhoea, but other causes as well. We assumed that diarrhoea cases among young children in the Kibera slum are mainly influenced by four factors:

1. The consumption of safe drinks. The less contaminated water a child drinks, the smaller should the chance be that he/she will suffer from diarrhoeal diseases. Therefore, we wanted to assess the percentage of safe drinks in the total daily liquid consumption by young children. We allocated treated water (SODIS, boiling, etc.), breast milk, undiluted soda, juices and the like to the category of presumed safe drinks. In contrast, we rated raw water, which refers here to water which was not treated by the end-consumers themselves, and other drinks which were mixed with raw water, as potentially contaminated liquids. We expected to find more sick children among households consuming a relatively high proportion of unsafe drinks. 
2. Hygiene behaviour. The promotion of hygienic practices holds an important place in the prevention of diarrhoeal diseases. Starting from the F-scheme presented here, the concept of hygiene represents several actions all of which should function as barriers to the transmission of faecal bacteria. There are two types of barrier (compare Curtis et al., 2000). Primary barriers are intended to prevent pathogens getting into the environment after defecation. This can be achieved by washing the hands after using the toilet, clean sanitary facilities and safe stool disposal. The second type of barrier refers to practices which stop faecal bacteria that have got into the environment from reaching a new host. It involves various behaviours: regular hand-washing with soap, covering of food and water tanks, keeping the household clean, controlling flies, etc. Because good hygiene behaviour should protect young children from getting diarrhoea, we expected to find a positive correlation between hygiene and the absence of diarrhoeal diseases in the investigated households.

3. The cleanliness of the household surroundings. Young children are not found only at home, but also spend a lot of their time in backyards, nearby streets and open spaces. The quality of their local environment may be important. The surroundings in a slum can be highly polluted, e.g. rubbish and faecal material is lying around, open sewerage drains are blocked. A child growing up in such a neighbourhood is exposed to health hazards because he/she regularly comes into contact with germs. We therefore assumed that the cleaner the immediate environment of a household, the less a young child would suffer from diarrhoea.

4. The quality of raw water. For households that treat their water anyway, the quality of the water they buy at the kiosks it not a crucial factor. But it is important for those children who regularly drink raw water (not treated at household level). We therefore expected that the bacterial quality of the water sold at kiosks and found in the households would at least have an influence among the households that give their children raw water to drink. 
The other focus of this research program was on cognition. Specifically, the aim was to find out how beliefs about diarrhoea are related to using SODIS and to hygiene behaviour. Unlike the cleanliness of a household's surroundings and the quality of raw water, these two factors are under the control of the households. So research interest focussed on the relationship between these health-improving practices and beliefs about the causes of diarrhoea in young children.

Our understanding of beliefs is rather broad. In this paper, we define beliefs as containing lay theories (Pits et al., 1996) as well as elements of scientific knowledge. Lay theories are constructed by people in order to interpret how and why certain things occur in their lives. The important point here is that they don't have any specialised knowledge about the relevant topic. However, elements of scientific knowledge refer to "real" knowledge, i.e. facts that are regarded by the modern scientific community to be proven and therefore true.

With this second component of the present study, we expected to gain an understanding of how beliefs, irrespective of whether they are objectively right or not, influence healthimproving behaviour such as the use of SODIS and hygiene practices. We hoped to find results which can generate conclusions in practice.

For constructing the belief variables, we consulted the Health Belief Model of Rosenstock (1974) and the Theory of Planned Behaviour of Ajzen $(1988,1991)$. We did not intend to test these concepts as a whole, but used them as a source of inspiration, so we took some components of these theories while developing some additional ideas. The diverse belief variables used in this study will now be presented: 
1. Perceived risk that young children get diarrhoea. With this variable we intended to estimate to what extent the households or individual respondents think that their young children are in danger of getting diarrhoeal diseases. We assumed that the higher this risk is assessed by the children's carers, the more they will be willing to take preventative measures, namely the adoption of SODIS and safe hygiene practices.

2. Perceived severity of young children's diarrhoea. Here the research interest was to evaluate to what extent the households rate young children's diarrhoea as a serious and therefore dangerous matter. We expected to find a positive relationship between perceived severity and performance of the health-improving behaviours mentioned above.

3. Lay ideas of the causes of young children's diarrhoea. This variable was designed to measure the prevalence of beliefs that attribute children's diarrhoea to supernatural causes (e.g. breaking of norms, witchcraft) and as well as of beliefs which explain children's diarrhoea by arguments that are apparently biomedical but prove on closer inspection to be based on biomedical causes that are correlative rather than causative (e.g. teething, sunken fontanels). We apply the following argument here: when a child's carers focus too strongly on supernatural or false biomedical causes of diarrhoea, they may take no or ineffective action against it. Following the concept of self-efficacy developed by Bandura (1982), a mother may underestimate her own influence on her young child's health. Feeling apathetic and unable to control events, she may neglect the health-improving behaviour known from biomedicine. Alternatively, she may attribute the incidence of diarrhoea to biomedical reasons that are not causal and therefore incorrect. This can lead to her taking sub-optimal measures for cure or prevention. Finally, we expected to find less SODIS application and good hygiene behaviour among those people who have strong lay ideas on the occurrence of diarrhoea. 
4. Biomedical knowledge of the causes of young children's diarrhoea. This variable is designed to assess to what degree the respondents can indicate correct biomedical reasons for children's diarrhoea when openly asked. Again, we assumed that people with good expertise in this matter would show more health-improving behaviour.

5. Knowledge of proper handling of water. With this variable we wanted to check if households know how to handle water safely. The greater the knowledge of this matter, the more would we expect health-improving behaviour to be practiced.

6. Belief in the key role of water in causing children's diarrhoea. We wanted to evaluate the significance given to water in explaining diarrhoeal diseases among children. Once again, our expectation was that the more highly the households rated the role played by water, the higher would be the chance of finding the use of SODIS and safe hygiene practices.

7. Social norms concerning water treatment. This last variable is about the relation between perceived pressure to treat water by the closest social environment, namely the family, and the application of SODIS. Although these two are not directly linked, we also wanted to relate this social pressure to hygiene behaviour. Our assumption: the more strongly a norm to treat water is perceived, the more will people perform health-improving behaviour such as SODIS and safe hygiene practices.

In summary, in this research programme we studied how four factors were related to young children's diarrhoea: consumption of safe water, hygiene behaviour, cleanliness of household surroundings and quality of raw water. Moreover, beliefs about the causes of children's diarrhoea were related to the use of SODIS and hygiene behaviour. For this purpose, we interviewed a sample of households in an urban slum in Nairobi. 


\section{METHODS}

The study was carried out in a certain part of the Kibera slum where a SODIS promotional project had previously taken place. Because of financial and time restrictions we could not conduct a controlled trial, so we ran a survey by interviewing a random sample of 500 households. The design is therefore correlative and not experimental. We developed a questionnaire which was used by ten local interviewers during the survey period of ten working days in late April and early May 2006. We additionally collected 102 water samples from households and water kiosks and tested them for faecal bacteria (E.coli).

The survey was conducted in the five villages of Mashimoni A, Mashimonoi B, Kisumu Ndogo, Mosque und Daranjani, all of which lie within Kibera. When population numbers are cumulated, we estimate that more than 100,000 people live in the five villages in total. The reason for limiting our study to a specific area of the slum was that we merely wanted to study places where SODIS had been already promoted by the relevant project activities. We did not expect a $100 \%$ application rate of SODIS in the selected villages, but were more likely to find some households that use SODIS more or less regularly while others did not use it at all. Nevertheless, all these households share similar conditions as regards their environment and infrastructure.

\subsection{Questionnaire}

The questionnaire was developed in several stages. In December 2005, the first version was pre-tested in Kibera and Mukuru, another slum in Nairobi: seven field workers conducted 120 interviews for this purpose. The results of this first test and the experience of carrying it out helped to revise the instruments used and to define further research procedures.

Some of the questions, which were all in English, were translated into Swahili. After being retranslated to English in order to ensure that the meaning had not changed in the translation 
process, the new Swahili questions were additionally incorporated into the questionnaire. Swahili is the second official language of the multiethnic state of Kenya after English and is widely spoken. After a number of in-depth interviews with households and further revisions, the ten field workers carried out a final pre-test with the questionnaire for training purposes. Thirty households were questioned for this purpose in Kibera. The final questionnaire contained items on different topics: there were questions about health, consumption of liquids and the hygiene behaviour of children younger than five years. Other questions examined the beliefs about the causes of young children's diarrhoea, and finally there were some additional questions on domestic hygiene and socio-demographic details. The interviewers were also instructed to observe some specific details of the household, which they noted in the questionnaire. Because most questions concerned the young children in the household, the field workers normally interviewed the main carer, usually the mother. In some cases, other relatives who look after the children were interviewed.

\subsubsection{Incidence of diarrhoea}

Children's health is a central dependent variable in the study. Therefore, one of the most important questions of the interview was about the incidence of diarrhoea among young children. The respondents were asked if any children of the household aged below five years had suffered from diarrhoea in the last two weeks. This evaluation represents a pointprevalence assessment. The time frame of two weeks is appropriate for this kind of question because longer periods may not be remembered accurately (Fewtrell \& Collford, 2004).

\subsubsection{Consumption of drinks}

Another crucial question was about the kind of drinks the young children consume. The question was open-ended, i.e. the field worker made no suggestions but encouraged the respondent to recall, as far as possible, all the types of liquids the young children drink on a 
normal day. For each drink mentioned, the interviewer asked how many cups the child might consume on a typical day on average. All the answers given were noted in a table. This data allowed us to calculate the percentage of safe and unsafe drinks in the daily liquid consumption of the young children. Thus, we assessed how many safe drinks (SODIS water, boiled water, undiluted soda, breast milk, packaged cows' milk, etc.) and how many potentially contaminated drinks (raw water, juice or soda mixed with raw water, etc.) the children usually consume. Where the respondents answered that they had switched between using SODIS and boiling depending on the weather, both of these were noted in the table and weighted equally.

\subsubsection{Hygiene behaviour}

It is not easy to assess the hygiene behaviour of young children and their carers accurately. The term hygiene refers to a group of actions and habits carried out during daily life. We focussed mainly on hand washing, one important aspect of hygiene. During the interview, the field workers asked a number of questions about this:

- How many times do your children below five years wash their hands per day? (open-ended question, scale: from 0 up to any number)

- Do the children below five years use soap for hand washing? If yes, how often? (openended question, answers were rated by interviewers on the scale: never [0], rarely [1], sometimes [2], mostly [3], always [4])

- When do your children below five years wash their hands? (open-ended question, scale: after toilet was mentioned [1], after toilet was not mentioned [0])

- How do you prepare fruit for eating? (open-ended question, scale: washing own hands before preparation was mentioned [1], washing own hands before preparation was not mentioned [0]) 
The measurement of hygiene behaviour usually faces methodical challenges (compare Manun'Ebo et al., 1997). When asking about hygiene-related practices, the problem of social desirability arises. Considering that such questions touch the private and intimate area of childcare, it may be assumed that some of the respondents fail to answer correctly. They may be embarrassed by some questions and ashamed to leave the outsider with the impression that they don't care for their children in a way which is perceived as socially desirable. As we did not want to rely only on the openness of the respondents, the field workers also estimated the hygiene behaviour of the households by observations that could be less distorted by the respondents. They were instructed to make the following observations:

- Is there soap in the household? (Observation, scale: no [0], yes [1])

- Is the household clean? (Observation, scale: very dirty [-1], dirty [0], clean [1], very clean [2]. To standardise their answers, the interviewers used criteria such as dirt, flies, uncovered food and rubbish lying around

- Are the hands of the respondent and the young children present clean? (Observation, scale: dirty [0], medium [0.5], clean [1])

Because we wanted to express the hygiene behaviour of a household with a single value, we constructed an index on the basis of these questions and observations. To ensure that the two items of frequency of hand washing and frequency of using soap would not be weighted disproportionately in the index, we scaled them down to $25 \%$ of their original value. We then cumulated the values of all seven questions and observations to a single hygiene index (Cronbach's alpha $=0.66)$.

\subsubsection{Cleanliness of the household surroundings}

The interviewers rated the cleanliness or pollution of the immediate household environment, i.e. the area immediately around the home and the nearby streets. The assessment was noted 
in four steps scaled from very dirty (1) to very clean (4). For standardisation purposes, we again used criteria such as rubbish and faecal material lying around, blocked open drains, etc.

\subsubsection{Testing raw water quality}

During the survey, we tested some water samples from the interviewed households. The field workers brought a sample of raw water from the last (sometimes the first) household interviewed that day. As already mentioned, raw water refers to water which was bought at kiosks and had not (yet) been treated at household level. It was normally stored in a container from which the interviewers collected the sample. In the case of a household that used SODIS, they additionally took a SODIS water sample where available. We used brand new empty plastic bottles for sampling, which we obtained directly from the manufacturer. We also collected some raw water samples directly from water kiosks in the five investigated villages. Overall, we tested 102 samples: 51 raw water samples from households, 35 SODIS water sample from households and 16 raw water samples from kiosks. All were collected at different places all around the five villages in the slum. We analysed them with the DELAGUA test kit from Oxfam for the Escherichia coli bacteria (E. coli). These faecal bacteria are a reliable indicator for assessing the degree of faecal contamination of a water sample.

One collected sample contained $100 \mathrm{ml}$ of water. The analysis showed how many colonyforming units were found per $100 \mathrm{ml}(\mathrm{CFU} / 100 \mathrm{ml})$. We classified the results on an eight-step scale:

- 1 stands for a sample with $0 \mathrm{CFU} / 100 \mathrm{ml}$. It is a strong indicator that the water does not contain any dangerous bacteria and is safe for drinking.

- 2 stands for a sample with up to $10 \mathrm{CFU} / 100 \mathrm{ml}$. It is relatively clean, and although not recommended, it could be drunk without major risk of getting sick. 
- 3 stands for a sample with a value between 11 and $50 \mathrm{CFU} / 100 \mathrm{ml}$. It is in the middle range and would be risky for drinking.

- 4 stands for a sample with a value of between 51 and $100 \mathrm{CFU} / 100 \mathrm{ml}$. It is heavily contaminated and drinking should be avoided at all costs.

- 5, 6, $7 \& 8$ stand for values from 100 to $500 \mathrm{CFU} / 100 \mathrm{ml}$ and more. Although it was possible to find values higher than $100 \mathrm{CFU} / 100 \mathrm{ml}$ with the test equipment used, the exact value above 100 could only be estimated. Thus, while 5 to 8 indicate an increase in contamination, they all are extremely polluted with faecal bacteria and would be very dangerous for drinking.

\section{$\underline{2.1 .6 \text { Beliefs }}$}

The questions concerning beliefs were openly asked. Except for a few cases, which are specified below, the answers were rated by the field workers on a five-step scale from 1 to 5 , from disagreement to agreement and from low probability to high probability. If the answer could not be rated clearly, the interviewer was instructed to repeat it in order to measure the respondent's opinion correctly. To further promote an adequate assessment of the opinion, the interviewers were instructed not only to note the verbal reactions to a question when rating the answer, but also to pay attention to physical signals (e.g. shaking the head firmly). This was important, for instance, in those cases when the interviewers had to decide whether someone simply agrees (4) or agrees absolutely (5). Unlike the rest of the questionnaire, the questions concerning beliefs were apt to change their meaning when translated. We therefore had them in both languages, Swahili and English, in the questionnaire, so that the field workers did not need to translate these items freely during the interview. The formulated items and the operationalisation of the belief variables are described in brief below: 


\section{Perceived risk that young children get diarrhoea}

- Are your young children at risk of getting diarrhoea?

(Scale: no [1], slightly [2], average [3], rather [4], very [5])

\section{Perceived severity of young children's diarrhoea}

For this variable, we took the average of the two following items:

- How likely is it that your young children will die if they had severe diarrhoea? (Scale: not at all [1], slightly [2], average [3], rather [4], very [5])

- How dangerous is it for young children to have diarrhoea? (Scale: not at all [1], slightly [2], average [3], rather [4], very [5])

\section{Lay ideas of the causes of young children's diarrhoea}

For this variable, we cumulated the values of the following items:

- Can young children get diarrhoea for supernatural reasons such as witchcraft or breaking norms? (Scale: definitely not [1], probably not [2], maybe [3], probably yes [4], definitely yes [5])

- Why do young children get diarrhoea? (Open-ended question. If supernatural reasons or incorrect biomedical explanations (e.g. teething, sunken fontanels, change of weather, weaning) were mentioned, then a point was given and all the points were finally cumulated so that the value of this item refers to a score)

\section{Biomedical knowledge of the causes of young children's diarrhoea}

- Why do young children get diarrhoea? (Open-ended question. If correct biomedical causes [e.g. contaminated water or food, dirty surroundings, insufficient hygiene, bacteria, viruses, parasites, worms, eating soil, poorly cooked food, diseases such as 
measles] were mentioned, then a point was given and all the points were finally cumulated so the value of this item refers to a score)

\section{Knowledge of proper handling of water}

- Can safe water be drunk safely if you mix it with untreated raw water?

(Scale: definitely not [1], probably not [2], maybe [3], probably yes [4], definitely yes [5])

6. Belief in the important role of water in causing children's diarrhoea

For this variable, we took the average of the three following items:

- Do germs in the drinking water cause diarrhoea and sickness? (Scale: definitely no [1], probably no [2], maybe [3], probably yes [4], definitely yes [5])

- How likely is it that untreated raw water contains germs? (Scale: not [1], slightly [2], average [3], rather [4], very [5])

- How likely is it that your young children get diarrhoea when they drink untreated raw water? (Scale: not [1], slightly [2], average [3], rather [4], very [5])

\section{Social norms concerning water treatment.}

- Do your family members want you to treat raw water before drinking? (Scale: definitely not [1], probably not [2], maybe [3], probably yes [4], definitely yes [5]) 


\subsection{Course of the study}

The ten interviewers were trained for several days by the first author. They were all local people; some even lived in the Kibera slum. Most of them were around 20 years old. We made sure that half the team of field workers were female because most interviews had to be conducted with mothers. But we also used male interviewers, mainly for security reasons. Young women walking through the slum are liable to be harassed. So for moving around in the field, we grouped the ten interviewers in mixed-gender pairs.

The whole team of field workers had already been involved in the SODIS project as promoters. So they knew exactly what they were talking and asking about as regards SODIS or hygiene behaviour. This had the advantage that we did not need to invest time on these topics and could concentrate our training strengths largely on survey methods such as interviewing subjects in an objective way and so forth. In addition, the field workers knew the slum area very well from their previous work and could always find their way in the chaos of muddy paths. And finally, from their previous promotion activity, the interviewers were familiar with the slum-dwellers' mentality and knew how to put them at their ease.

The survey took place during ten working days between April $24^{\text {th }}$ and May $12^{\text {th }}, 2006$. Bad weather made it impossible to carry out any interviews during the middle of this period. The time frame for the study was intentionally planned for the early rainy season. At this time of the year, a higher prevalence of diarrhoea can be expected among the population so that any health-improving behaviour would be more easily measurable. 
Each field worker pair was assigned a village in which to conduct the interviews. We made sure that no-one carried out interviews in a village where he or she had worked as a SODIS promoter. This eliminated any danger that the interviewers might already know the household members from their earlier promotional activity.

We expected each field worker to conduct five interviews a day. This task could normally be accomplished within a few hours, as an interview usually lasted between 25 and 40 minutes. The households to be interviewed were selected at random so that the results were representative for all households with young children within the studied area of Kibera. Any confusing influences should be equally distributed through random selection.

To select the households, the interviewers followed a random route procedure (HoffmeyerZlotnik, 1997). Each day, the pairs walked together through the allocated villages. They chose a path randomly and started counting the households to their right and left. Sometimes the structure of the settlement made it necessary for the interviewers to enter compounds in order to count the households. At the tenth household, they asked for an interview. If there was nobody at home there, the residents had no children below five years or did not want to participate in the survey, the interviewers would ask the eleventh, twelfth or thirteenth households to participate. If the children's carer was not at home, the interviewers asked when she would return and came back later for the interview. If the carer was too busy at the moment, they asked if they could come back later. Each interview was conducted by just one person, while the other one carried out another interview in another household. After finishing the interviews, the pair got together again and went to another corner of the village where they again chose a path randomly and restarted counting the households. The counting system ensured that the interviewers did not select the households in an arbitrary manner. 
When asking at a household for survey participation, the interviewers proceeded as follows: they introduced themselves and explained their mission, namely to conduct a survey about health and the consumption of drinks by young children. They asked the respondents to answer their questions in an open and honest manner and told them that there were no right or wrong answers in the interview. They made it clear that all the answers would be kept confidential and would only be used for scientific purposes. SODIS was not mentioned at all in the introduction. After being asked if there were any children below five years living in the household, the children's carer was asked to participate in the survey.

In most cases, the carers agreed to be interviewed. Only about five to ten percent of those who were asked refused to take part. Sometimes there was no-one at home to interview. But when someone was at home, young children were also present. The interviews were held inside the house. Usually, several chairs stood in the restricted space of the one-room household. By holding the interview inside, the respondents were not disturbed and the interviewers could make observations about the domestic hygiene.

We accompanied the field workers to check the data quality. We joined them at random times during a working day and supervised them in selecting the households and interviewing the respondents. The data from the 500 questionnaires was entered manually into a computer and was analysed with the statistics software SPSS 11 and Excel.

\subsection{Description of the questioned sample}

We carried out a total of exactly 500 interviews in the survey. Because the populations of the five investigated villages differ greatly in some cases, we did not conduct the same number of interviews in each village. We tried to adjust our sample sizes to the different population ratios of the villages. However, the average sample size was 100 . We questioned only those 
households in which children below five years of age were present. Since the child population in Kibera is very high, the interviewers had no difficulty in finding families with young children. In most cases (84\%) the questioned carer was the mother. The rest of the interviews $(16 \%)$ were carried out with grandmothers, sisters, aunts, fathers and brothers of the young children. The language of the interview was Swahili in about $65 \%$ of cases and a mixture of Swahili and English in 25\%. The remaining interviews (about 10\%) were conducted only in English or in a mixture of another local language with English or Swahili.

There were between three and 11 people living in the households interviewed. The average household size was $5.3(\mathrm{SD}=1.57)$ people. The vast majority of households $(>90 \%)$ had between one and four children below the age of 16 , the average being $2.54(\mathrm{SD}=1.21)$. At least one of these children was below five years of age, as this was an interview criterion. On average, the households had 1.43 children aged below five years $(\mathrm{SD}=0.57)$. Whereas $60 \%$ of all households had just one young child, 36\% had two. The remaining $4 \%$ of households comprised 16 households with three young children and one with four. When these numbers are added together, we find that the 500 households comprised a total of 717 children below the age of five years. The average age of these young children was calculated to be 2.43 years. A value close to 2.5 was expected because the children had to be between 0.1 and five years of age to be classified as young children. 


\section{RESULTS}

Before addressing the research questions with the data obtained, we will take a look at the descriptive statistics for some key variables. Table 1 below contains these variables, their scales and central values.

Table 1: Characterisation of Key Variables

\begin{tabular}{|c|c|c|c|c|c|c|}
\hline Variable & Scale & $\mathrm{N}$ & M & SD I & Dispersion & Range \\
\hline Diarrhoea among young childrenno & incidence $=0$, incidence $=1$ & 500 & 0.33 & .469 & 0,1 & 1 \\
\hline Consumption of SODIS water & not consuming $=0$, consuming $=1$ & 500 & 0.69 & .463 & 0,1 & 1 \\
\hline Consumption of boiled water & not consuming $=0$, consuming $=1$ & 500 & 0.53 & .500 & 0,1 & 1 \\
\hline Consumption of chlorinated water & not consuming $=0$, consuming $=1$ & 500 & 0.10 & .300 & 0,1 & 1 \\
\hline Consumption of raw water & not consuming $=0$, consuming $=1$ & 500 & 0.23 & .419 & 0,1 & 1 \\
\hline $\begin{array}{l}\text { Percentage of safe drinks in } \\
\text { the total daily consumption of liquids }\end{array}$ & Percent $(\%)$ & 485 & 94.55 & $\begin{array}{l}12.07 \\
\text { to } 100\end{array}$ & 14.3 & 85.7 \\
\hline $\begin{array}{l}\text { Cleanliness of the } \\
\text { household surroundings }\end{array}$ & $\begin{array}{l}\text { Scale from } 1 \text { to } 4 \\
1=\text { very dirty } \\
4=\text { very clean }\end{array}$ & 500 & 2.95 & 0.517 & 1 to 4 & 3 \\
\hline Hygiene index & $\begin{array}{l}\text { Scale } \\
\text { Low value = poor hygiene behaviour } \\
\text { High value = good hygiene behaviour }\end{array}$ & 475 & 6.57 & $\begin{array}{l}1.67 \\
\text { to } 10.5\end{array}$ & 1 & 9.5 \\
\hline Quality of SODIS water & $\begin{array}{l}\text { Scale from } 1 \text { to } 8 \\
1=\text { no contamination (E.coli) } \\
8=\text { extremely contaminated (E.coli) }\end{array}$ & 35 & 1.57 & 1.399 & 1 to 7 & 6 \\
\hline Quality of raw water in the households & $\begin{array}{l}\text { Scale from } 1 \text { to } 8 \\
1=\text { no contamination (E.coli) } \\
8=\text { extremely contaminated (E.coli) }\end{array}$ & 51 & 4.86 & 2.592 & 1 to 8 & 7 \\
\hline Quality of raw water from kiosks & $\begin{array}{l}\text { Scale from } 1 \text { to } 8 \\
1=\text { no contamination (E.coli) } \\
8=\text { extremely contaminated (E.coli) }\end{array}$ & 16 & 2.94 & 2.594 & 1 to 8 & 7 \\
\hline $\begin{array}{l}\text { Quality of raw water (households \& kiosks) } \\
\text { All missing values were replaced by } \\
\text { an average peak generated from villages }\end{array}$ & $\begin{array}{l}\text { Scale from } 1 \text { to } 8 \\
1=\text { no contamination (E.coli) } \\
8=\text { extremely contaminated (E.coli) }\end{array}$ & 500 & 4.47 & .918 & 1 to 8 & 7 \\
\hline $\begin{array}{l}\text { Perceived risk that young children } \\
\text { get diarrhoea }\end{array}$ & $\begin{array}{l}\text { Scale from } 1 \text { to } 5 \\
1=\text { low, } 5=\text { high }\end{array}$ & 499 & 4.89 & .445 & 1 to 5 & 4 \\
\hline $\begin{array}{l}\text { Perceived severity of young } \\
\text { children's diarrhoea }\end{array}$ & $\begin{array}{l}\text { Scale from } 1 \text { to } 5 \\
1=\text { not serious, } 5=\text { very serious }\end{array}$ & 498 & 4.93 & .255 & 3 to 5 & 2 \\
\hline $\begin{array}{l}\text { Lay ideas of the causes of young } \\
\text { children's diarrhoea }\end{array}$ & $\begin{array}{l}\text { Scale from } 1 \text { to } 7 \\
1=\text { none, } 7=\text { many }\end{array}$ & 498 & 2.66 & 1.55 & 1 to 7 & 6 \\
\hline $\begin{array}{l}\text { Biomedical knowledge of the causes } \\
\text { of young children's diarrhoea }\end{array}$ & $\begin{array}{l}\text { Mentions were cumulated } \\
0=\text { poor knowledge, } 6=\text { good knowledge }\end{array}$ & 497 & 3.78 & .961 & 0 to 6 & 6 \\
\hline Knowledge of proper handling of water & $\begin{array}{l}\text { Scale from } 1 \text { to } 5 \\
1=\text { poor knowledge, } 5=\text { good knowledge }\end{array}$ & 499 & 4.79 & 644 & 1 to 5 & 4 \\
\hline $\begin{array}{l}\text { Belief in the key role of water in } \\
\text { causing children's diarrhoea }\end{array}$ & $\begin{array}{l}\text { Scale from } 1 \text { to } 5 \\
1=\text { very little, } 5=\text { very high }\end{array}$ & 497 & 4.91 & .261 & 3 to 5 & 2 \\
\hline Social norms concerning water treatment & $\begin{array}{l}\text { Scale from } 1 \text { to } 5 \\
1=\text { no pressure, } 5=\text { high pressure }\end{array}$ & 497 & 4.84 & .528 & 1 to 5 & 4 \\
\hline
\end{tabular}


About one third of the households stated that their children below five years of age had recently suffered from diarrhoea. The question as to which liquids the children usually consumed gave the following results (multiple answers possible): almost $70 \%$ of the young children drank SODIS water, 53\% consumed boiled water and one tenth of them were given chlorinated water to drink. Just $23 \%$ of the questioned households said that their young children drank raw water. Naturally, other drinks (tea, milk, etc.) were also mentioned, but they are not listed in the table because of limited space. For every liquid mentioned, the field workers asked about the amount the child normally consumed on a typical day. This allowed us to calculate the percentage of presumably safe drinks in the total daily consumption of all liquids. The average value of this variable is high, at $94.55 \%(\mathrm{SD}=12.07)$.

For the hygiene index, we obtained values of between 1 and 10.5, with a mean of 6.57 $(\mathrm{SD}=1.67)$. The results of the water tests are as follows: most of the 35 analysed samples of SODIS water collected from the households were uncontaminated or had just minor contaminations. The average of the scaled values was $1.57(\mathrm{SD}=1.399)$. In contrast, most of the 51 tested samples of raw water from households were severely contaminated. The mean value was $4.86(\mathrm{SD}=2.592)$. The 16 samples of raw water collected directly at the source, i.e. from the water kiosks, were a little less infected: $\mathrm{M}=2.94, \mathrm{SD}=2.594$. The findings of the water tests strongly support the assumption that the majority of SODIS users know how to apply SODIS correctly. They can therefore obtain water of improved quality. However, the results of the raw water analyses indicate that irrespectively of whether the water from the kiosks is good or not, it is always additionally contaminated by the households after being purchased. Because we did not test the raw water of all households, we created a raw-water quality variable for all 500 questioned households. For this purpose, we gave all households from which we had not collected raw water samples an average peak formed by the results of the raw water tests of the households and water kiosks in their specific village. 
We do not present any detailed values for the various questions regarding beliefs. The relevant data can be studied in Table 1. Just one remark: we obtained a ceiling or floor effect for the questions with a scale from 1 to 5, which applies to all but two exceptions. Otherwise, these variables showed little variance.

\subsection{Factors influencing cases of diarrhoea among young children}

We calculated logistic regressions to analyse the factors influencing the incidence of young children's diarrhoea. Table 2 contains the results.

Table 2: Logistic Regression Analyses ( 1 to 3 ) on Young Children's Diarrhoea ( $0=$ no, $1=$ yes)

\begin{tabular}{|c|c|c|c|c|c|c|c|c|c|c|c|c|}
\hline \multirow[t]{2}{*}{ Factors } & \multicolumn{4}{|c|}{ Regression 1} & \multicolumn{4}{|c|}{ Regression 2} & \multicolumn{4}{|c|}{ Regression 3} \\
\hline & $\mathrm{B}$ & SE B & $\operatorname{Exp}(B)$ & $\mathrm{p}$ & $\mathrm{B}$ & SE B & $\operatorname{Exp}(B)$ & $\mathrm{p}$ & $\mathrm{B}$ & SE B & $\operatorname{Exp}(B)$ & $\mathrm{p}$ \\
\hline $\begin{array}{l}\text { Consumption } \\
\text { of SODIS water }\end{array}$ & -1.208 & .295 & .299 & $.000 * *$ & --- & --- & --- & --- & --- & -- & --- & --- \\
\hline $\begin{array}{l}\text { Consumption } \\
\text { of raw water }\end{array}$ & 3.278 & .383 & 26.51 & $.000 * *$ & --- & --- & --- & --- & --- & --- & --- & --- \\
\hline $\begin{array}{l}\text { Cleanliness of the } \\
\text { surroundings }\end{array}$ & $\begin{array}{l}\text { househ } \\
-.615\end{array}$ & .280 & .541 & $.028 *$ & -.879 & .267 & .415 & $.001 * *$ & -.396 & .301 & .673 & .188 \\
\hline $\begin{array}{l}\text { Quality of } \\
\text { raw water }\end{array}$ & .039 & .152 & 1.040 & .796 & .110 & .138 & 1.116 & .428 & .154 & .163 & 1.167 & .345 \\
\hline Percentage of saf & drinks & the total & f daily con & nsumptic & & & & & & & & \\
\hline of liquids & --- & --- & --- & --- & -.172 & .022 & .842 & $.000 * *$ & -.149 & .021 & .862 & $.000 * *$ \\
\hline $\begin{array}{l}\text { Hygiene } \\
\text { behaviour }\end{array}$ & --- & --- & --- & -- & --- & --- & --- & --- & -.584 & .105 & .558 & $.000 * *$ \\
\hline Constant & .893 & 1.045 & 2.441 & .393 & 17.746 & 2.328 & 5.1 & $.000 * *$ & 17.563 & 2.375 & 4.2 & $.000 * *$ \\
\hline & R1: & lker & $555 * *$ & $\mathrm{~N}=500$ & R2: & lken & 487 & $=485$ & R3: & elke & $545 * *$ & $\mathrm{~N}=462$ \\
\hline
\end{tabular}

We proceeded in steps, the aim of the first regression analysis being to see if the following four factors could predict the occurrence of diarrhoea: consumption of SODIS water, consumption of raw water, cleanliness of the household surroundings and the quality of raw water in the household. All were significant except for the quality of the raw water. These 
factors could explain the variance of the dependent variable to $55.5 \%$ (Nagelkerke). Therefore a child who drinks SODIS water but no raw water and lives in a household with relatively clean surroundings has a significantly higher chance of avoiding diarrhoea.

The first regression showed that drinking SODIS water is directly linked to the children's health. We then replaced the two factors of consumption of SODIS water and raw water with the broader factor of the percentage of safe drinks in the daily consumption of liquids by young children. We calculated a second logistic regression (see Table 2), whose results again show that whereas the cleanliness of household surroundings was significant, the quality of the raw water was not. The new factor of the percentage of safe water also proved to be highly significant. This time, the regression could explain $48.7 \%$ of the variance. Thus children who live in a household with relatively clean surroundings and mainly consume safe drinks have a higher chance of not suffering from diarrhoea.

In the third regression analysis, we additionally included an index which represents the hygiene behaviour (see Table 2). The new factor proved to be as significant as the percentage of safe drinks. Again, the quality of raw water was not significant. Surprisingly, the cleanliness of the household surroundings was not significant this time either. However, this makes intuitive sense and may be interpreted in the following way: when hygiene is included in the regression, the cleanliness of the surroundings is no longer so important because good hygiene practices allow a mother to protect her children from a polluted environment to a certain extent.

The variance was shown to be $54.5 \%$. Finally, only two of the four factors that we assumed would cause diarrhoea among young children proved to be significant. Our data shows that a child in the Kibera slum has a lower risk of contracting diarrhoea when he/she consumes a high percentage of safe drinks and lives in a household with relatively good hygiene behaviour. 


\subsection{The relationship between beliefs and the use of SODIS}

The results of another logistic regression are presented in Table 3. Its aim was to determine how the beliefs about the causes of children's diarrhoea are related to the use of SODIS (binomial scale: non-user vs. user).

Four of the seven variables concerning beliefs were significant. A higher likelihood of using SODIS was linked with higher biomedical knowledge of the causes of young children's diarrhoea, higher knowledge of proper handling of water, stronger beliefs in the important role of water in causing diarrhoea, and finally, higher social norms concerning water treatment. The regression explained the variance by a relatively low $24.5 \%$. Three variables were not significantly associated with the use of SODIS: the perceived risk that young children get diarrhoea, the perceived severity of young children's diarrhoea and lay ideas about the causes of young children's diarrhoea.

Table 3: Logistic Regression Analysis on SODIS use ( $0=$ no, $1=y e s)$

\begin{tabular}{lllll}
\hline Variables & B & SE B & Exp(B) & p \\
\hline Perceived risk that young children get diarrhoea & 0.028 & 0.241 & 1.029 & .907 \\
Perceived severity of young children's diarrhoea & -0.385 & 0.470 & 0.681 & .413 \\
Lay ideas of the causes of young children's diarrhoea & 0.059 & 0.074 & 1.060 & .428 \\
Biomedical knowledge of the causes of young children's diarrhoea & 0.317 & 0.113 & 1.373 & $\mathbf{. 0 0 5}^{* *}$ \\
Knowledge of proper handling of water & 0.479 & 0.205 & 1.614 & $\mathbf{. 0 1 9}^{*}$ \\
Belief in the key role of water in causing children's diarrhoea & 2.704 & 0.833 & 14.938 & $\mathbf{. 0 0 1}^{* *}$ \\
Social norms concerning water treatment & 0.919 & 0.328 & 2.506 & $\mathbf{. 0 0 5}^{* *}$ \\
Constant & -18.874 & 4.279 & 0.000 & $.000^{* *}$ \\
\hline
\end{tabular}

$\mathrm{R} 1:$ Nagelkerke $=.245^{* *}, \mathrm{~N}=491$ 


\subsection{The relationship between beliefs and hygiene behaviour}

We used a linear regression model to calculate how far various beliefs could predict the values of the hygiene behaviour index. The results in Table 4 reveal that three variables were significant: there was a positive correlation between hygiene behaviour and greater biomedical knowledge of the causes of young children's diarrhoea, stronger beliefs in the important role played by water in causing diarrhoea and a stronger social pressure felt by the respondents for water treatment. However, the regression could explain the variance by no more than $15.9 \%$.

Table 4: Linear Regression Analysis on Hygiene Behaviour Index

\begin{tabular}{lllll}
\hline Variables & B & SE B & Exp(B) & $\mathrm{p}$ \\
\hline Perceived risk that young children get diarrhoea & -0.048 & 0.162 & -0.013 & .766 \\
Perceived severity of young children's diarrhoea & -0.350 & 0.281 & -0.055 & .213 \\
Lay ideas of the causes of young children's diarrhoea & 0.084 & 0.047 & 0.079 & .074 \\
Biomedical knowledge of the causes of young children's diarrhoea & 0.329 & 0.075 & 0.190 & $\mathbf{. 0 0 0 * *}$ \\
Knowledge of proper handling of water & 0.262 & 0.143 & 0.095 & .068 \\
Belief in the key role of water in causing children's diarrhoea & 1.671 & 0.388 & 0.246 & $\mathbf{. 0 0 0 * *}$ \\
Social norms concerning water treatment & 0.348 & 0.166 & 0.107 & $\mathbf{. 0 3 7 *}$ \\
Constant & -2.529 & 2.139 & & .238 \\
\hline
\end{tabular}

Adjusted $\mathrm{R}^{2}=.159^{* *}, \mathrm{~N}=465$ 


\section{DISCUSSION}

The purpose of this research project was to study the factors which determine young children's diarrhoea in an urban slum setting as well as the link between beliefs about the causes of children's diarrhoea and health improving behaviour, specifically the use of SODIS and good hygiene behaviour.

We postulated four factors which influence the incidence of diarrhoea among young children in the selected case study, namely the Kibera slum in Nairobi: the consumption of safe drinks, the hygiene behaviour, the cleanliness of the household surroundings and the quality of the raw water. The first two proved to be significant, the second two did not. From our stepwise procedure in calculating the regressions, we learned that the cleanliness of the household surroundings was an important predictor for diarrhoea as long as the hygiene behaviour was not included. However, our calculations show that the quality of raw water never played a significant role for diarrhoea. This may be because this quality is nearly always bad in the households, so the high level of contamination would not yield enough variation. In fact, a look at the data shows that while only little more than $20 \%$ of the children actually drank raw water, the vast majority of them suffered from diarrhoea. So there might be no raw water in households which can be safely consumed. But it is also conceivable that methodical problems (not enough samples tested, replacing missing values with an average) were responsible for a lack of a significant effect in this factor.

As a conclusion from our findings, we state that behavioural factors are more important than environmental ones as regards the incidence of young children's diarrhoea. Carers can protect their children's health by giving them no raw water or only treated water to drink and by showing and ensuring good hygiene behaviour. This seems to be crucial, whereas environmental factors such as cleanliness of the household surroundings and the quality of the 
raw water, both of which are largely beyond the control of the households, are unimportant. However, we should be aware that these findings were generated in an urban slum in which most households are exposed to considerable pollution anyway, so the differences among them may be seen against the background of a very high pollution level. The quality of the environment could become of real significance when we study settlements with more radically differing conditions, e.g. by comparing a slum with a middle class quarter. Nevertheless, the results show that slum dwellers are not helplessly exposed to health risks; they have at least some control over the well-being of their offspring.

The other component of the research project consisted of relating beliefs concerning diarrhoea to the use of SODIS and hygiene behaviour. In summary, we found that the variables focussing on a biomedical knowledge of children's diarrhoea as well as the social norm for treating water could predict the use of SODIS and hygiene behaviour. In contrast, the perceived risk that young children get diarrhoea, the perceived severity of their diarrhoea and lay ideas about the causes of this diarrhoea showed no significant link to the use of SODIS or hygiene behaviour. In fact, nearly all the households questioned stated that children's diarrhoea is quite likely and often severe; there was not much variance here. The differences lay more in how much the respondents really knew about the causes of children's diarrhoea. Even tough the lay beliefs proved not to be important. Why they were not, is unclear. It is quite possible that beliefs held about the causes of diarrhoea may simultaneously contain biomedical elements and lay concepts.

Finally, we conclude from our results that children's carers with good biomedical knowledge of the causes of diseases can take more appropriate action against them. In our case, this involves water treatment (e.g. by SODIS) and improved health practices. The likelihood of them doing so becomes even higher when they feel some kind of social pressure. 
However, since the calculated regressions could not explain very much of the variance, the findings about beliefs should be interpreted with some caution. Beliefs alone might not be enough to explain health-improving behaviour, as the costs and accessibility of this behaviour should also be taken into account. These factors were omitted in this study because SODIS and hygiene practices do not normally need costly material or financial resources.

\subsection{Limitations and further directions}

We did not consider all the potential factors known to influence young children's diarrhoea (Curtis et al., 2000): thus we did not include the broad issue of sanitary facilities. Another factor we did not evaluate was the amount of water used per person and day (Gorter et al., 1991; Cairncross, 1997). Because of insufficient access to water or financial constraints, many households may just have a small amount of water for their daily use. So people tend to save water in the "relatively unimportant" fields of domestic and personal hygiene. The result is that hands get washed less often and so forth. Future research on the incidence of children's diarrhoea should also include these factors.

In this study, we used several belief variables concerning different aspects of a biomedical knowledge of diarrhoea. There is clearly some conceptual overlap between these variables. Because nearly all of them were significant, one could argue that it would be more reasonable to combine them in a single factor estimating the overall biomedical knowledge. Another problem was the measurement of the various beliefs: the answers showed relatively few variances. Perhaps the methodical procedure of presenting the households with a question and estimating their approval on a fixed scale was not the most optimal way of assessing their beliefs. For instance, the question "Are your young children at risk of getting diarrhoea?" usually provoked an immediate 'yes' response and gave little or no scope for any variance within the five-step scale. It is clearly challenging to assess the beliefs of illiterate people, as 
women in third-world slums often are, and a sophisticated approach is needed. Although our method yielded results, we may well rethink a new study and possibly revise it to make it more effective in representing the opinions and beliefs of the respondents in the most accurate way.

Another point which needs to be addressed is the fact that the people we hired as interviewers had previously worked as SODIS promoters in the slum. It may be considered problematic to involve personnel who promoted SODIS, and had therefore implemented the intervention, in a research project that is a kind of evaluation of the latter. The interviewers might not be impartial. In training the interviewers, we placed much weight on this aspect and tried to prevent any interviewer bias. We also carried out control visits in the field for this purpose. But it was also helpful to use SODIS promoters as interviewers because they knew all about the local water problems and hygiene behaviour. They were well acquainted with the slum area and the dwellers' mentality. From their promotional activity they knew exactly how to approach the slum inhabitants and could always find their way in the chaos of muddy paths. Due to their prior experience, they were also aware of the risks of working and moving around in the slum.

A general but not specific weakness of the study is that it represents a survey rather than a controlled trial. The cross-section design that we applied merely allowed us to show which variables are linked to each other. We can of course make assumptions as to how the different variables affect the others, but it is ultimately impossible to present concluding statements about the causality of the relationships between variables. For instance, we cannot definitely state whether the SODIS project activities led to an improved biomedical knowledge of diarrhoea and then to the adoption of SODIS and improved hygiene behaviour, or if rather the opposite was the case: the relevant beliefs were already present and the more aware 
respondents were open to try a new kind of water treatment like SODIS. To answer that question in a conclusive way, an experimental longitudinal section study would have to be conducted. Households would have to be accompanied over a certain period and questioned several times. Such a procedure would allow us to determine not only the causality of the variables but also, for instance, how often SODIS is used by the various households - which was not feasible with the present research project. We were unable to differentiate effectively whether someone used SODIS as often as possible or only occasionally.

\subsection{Practical implications}

Our research showed that drinking treated rather than raw water in combination with good hygiene behaviour leads to a lower incidence of diarrhoea among young children. In our case, the treatment of water meant the use of SODIS to a large extent. So the usefulness of this technique was confirmed once again (Conroy et al., 1996, 1999, 2001; Hobbins, 2003; Rose et al., 2006), especially for an urban slum setting where water should be purified at household level. We suggest that SODIS, with its advantages as noted in this paper, needs to be further promoted in developing countries along with hygiene education. Our results indicate that treating water and general hygiene behaviour are more important than the cleanliness of the surroundings as a means of protecting young children from diarrhoea. This means that limited resources would be better invested in water treatment and hygiene projects than in cleaning up neighbourhoods.

In addition, education campaigns on the biomedical causes of children's diarrhoea could, next to the development of strong social pressure to treat water before drinking it, further facilitate the acceptability of SODIS and the willingness to treat water and improve domestic hygiene practices. 


\section{REFERENCES}

Ajzen, I. (1988). Attitudes, personality, and behavior. Milton-Keynes, England: Open

University Press \& Chicago, IL: Dorsey Press.

Ajzen, I. (1991). The theory of planned behaviour. Organizational Behavior and Human Decision Processes, 50, 179-211.

Altherr, A.-M., Mosler, H.-J., Tobias, R. \& Butera, F. (2006). Attitudinal and Relational Factors Predicting the Use of Solar Water Disinfection: A Field Study in Nicaragua. Health Education \& Behavior, 20 (5), 1-14.

APHRC - African Population and Health Research Center (2002). Population and Health Dynamics in Nairobi's Informal Settlements. Retrieved April, 8, 2007, from http://www.aphrc.org/publications.asp?year=2002

Bandura, A. (1982). Self-efficacy mechanism in human agency. American Psychologist, 37, 122-147.

Bongi, S. \& Morel, A. (2005). Understanding Small Scale Providers of Sanitation Services: A Case Study of Kibera. Report. Water and Sanitation Program, Africa, Nairobi.

Cairncross, S. (1997). More water: better health. People and the Planet 6, 3.

Conroy, R.M., Meegan, M.E., Joyce, T., McGuigan, K. \& Barnes, J. (1999). Solar disinfection of water reduces diarrhoeal disease, an update. Arch Dis Child, 81, 337-338.

Conroy, R.M., Meegan, M.E., Joyce, T., McGuigan, K. \& Barnes, J. (2001). Solar disinfection of drinking water protects against cholera in children under 6 years of age. Arch Dis Child, 85, 293-295.

Conroy, R.M., Meegan, M.E., Joyce, T., McGuigan, K. \& Barnes, J.(1996). Solar disinfection of drinking water and diarrhoea in Maasai children: a controlled field trial. The Lancet, 348, 1695-1697. 
Curtis, V., Cairncross, S. \& Yonli, R. (2000). Domestic hygiene and diarrhoea - pinpointing the problem. Review. Tropical Medicine and International Health. 5 (1), 22-32.

Fewtrell, L. \& Colford, J.M. (2004). Water, Sanitation and Hygiene: Interventions and Diarrhoea. A Systematic Review and Meta-Analysis. The World Bank. Retrieved April, 8, 2007, from http://siteresources.worldbank.org/HEALTHNUTRITIONANDPOPULATION/Resources/28 1627-1095698140167/Fewtrell\&ColfordJuly2004.pdf

Fewtrell, L., Kaufmann, R., Kay, D., Enanoria, W., Haller, L. \& Colford, J. (2005). Water, sanitation, and hygiene interventions to reduce diarrhoea in less developed countries: a systematic review and meta-analysis. Lancet Infect Dis, 5, 42-52.

Gorter, A.C., Sandiford, P., Davey Smith, G. \& Pauw, J.P. (1991). Water supply, sanitation and diarrhoeal disease in Nicaragua: results from a case control study. Int J Epidemiol, 20, 527-33.

HDR - Human Development Report (2006). United Nations Development Program. Retrieved April, 8, 2007, from http://hdr.undp.org/hdr2006/pdfs/report/HDR06-complete.pdf

Heri, S. \& Mosler, H.J. (submitted). Factors Influencing the Diffusion of Solar Water Disinfection: A Field Study in Bolivia.

Hobbins, M. (2003). The SODIS Health Impact Study, Ph.D. Thesis, Swiss Tropical Institute Basel.

Hoffmeyer-Zlotnik, J.H.P. (1997). Random-Route-Stichproben nach ADM. In S. Gabler \& J.H.P. Hoffmeyer-Zlotnik (Eds.), Stichproben in der Umfragepraxis (pp.33-42). Opladen: Westdeutscher Verlag.

Manun'Ebo, M., Cousens, S., Haggerty, P., Kalengaie, M., Ashworth, A. \& Kirkwood, B. (1997). Measuring hygiene practices: a comparison of questionnaire with direct observations in rural Zaire. Tropical Medicine and International Health, 2 (11), 1015-1021. 
Meierhofer, R. \& Wegelin, M. (2002). Solar Water Disinfection: A Guide for the Application of SODIS (SANDEC Rep. No. 06/02). Dübendorf, Switzerland: EAWAG/SANDEC.

Retrieved February, 8, 2007, from http://www.sodis.ch/files/SODIS_Manual_english.pdf

Pitts, M., McMaster, J., Hartmann, T. \& Mausezahl, D. (1996). Lay beliefs about diarrhoeal diseases: Their role in health education in a developing country. Soc. Sci. Med, 43 (8), 1223 1228.

Rose, A., Roy, S., Abraham, V., Holmgren, G., George, K., Balraj, V., Abraham, S., Muliyil, J., Joseph, A. \& Kang, G. (2006). Solar disinfection of water for diarrhoeal prevention in Southern India. Arch Dis Child, 91 (2), 139-141.

Rosenstock, I. (1974). Historical Origins of the Health Belief Model. Health Education Monographs, 2 (4).

Wagner, J.M. \& Lanoix, J.N. (1958). Excreta Disposal for Rural Areas and Small Communities. WHO Monograph series No 39, WHO, Geneva.

WHO (2005). Water, sanitation and hygiene links to health. Facts and Figures - updated November 2004. Retrieved February, 8, 2007, from http://www.who.int/water_sanitation_health/factsfigures2005.pdf WSP - Water and Sanitation Program (2005a). Rogues No More? Water Kiosk Operators Achieve Credibility in Kibera. Field Note, WSP-Africa, Nairobi.

WSP - Water and Sanitation Program (2005b). Understanding Small Scale Providers of Sanitation Services: A Case Study of Kibera. WSP-Africa, Nairobi. 


\section{ANNEX: QUESTIONNAIRE}

Because of limited space the following form is downsized. The applied questionnaire was larger (letters, tables).

\section{Health and Water Questionnaire: Children below 5 years}

Name of the interviewer: Location:

Name of the person interviewed: Date:

Mother $\square \quad$ Grandmother $\square \quad$ Other:

\section{Diarrhoea Incidence}

1.1. How many people live in your household?

1.2. How many of these are children (below 16 years)?

1.3. How many children below 5 years do live in your household?

1.4. What do you think: Why do young children get diarrhoea?

$\rightarrow$ OPEN ANSWER, MULTIPLE RESONSES

$\square$ just normal, natural

$\square$ bad / dirty food

$\square$ bad / dirty water

$\square$ dirty surroundings

$\square$ bad hygiene / dirty hands

$\square$ other reasons:

1.5. Has any of your children below 5 years suffered from diarrhoea in the past 2 weeks (14 days)?

$\square \quad$ No

$\square \quad$ Yes

1.6. Type and Frequency of Diarrhoea

\begin{tabular}{|c|c|c|c|c|}
\hline & Name \& age child: & Name \& age child: & Name \& age child: & Name \& age child: \\
\hline $\begin{array}{l}\text { How often did the child } \\
\text { have diarrhoea in the past } \\
2 \text { weeks? } \\
\text { (cases) }\end{array}$ & $\begin{array}{l}\square 1 \mathrm{x} \\
\square 2 \mathrm{x} \\
\square \text { more }\end{array}$ & $\begin{array}{l}\square 1 \mathrm{x} \\
\square 2 \mathrm{x} \\
\square \text { more }\end{array}$ & $\begin{array}{l}\square 1 \mathrm{x} \\
\square 2 \mathrm{x} \\
\square \text { more }\end{array}$ & $\begin{array}{l}\square 1 \mathrm{x} \\
\square \text { 2x } \\
\square \text { more }\end{array}$ \\
\hline $\begin{array}{l}\text { For how many days did } \\
\text { the diarrhoea last? }\end{array}$ & $\begin{array}{l}\square 1 \text { day } \\
\square 2 \text { days } \\
\square 3 \text { days } \\
\square \text { more than } 3 \text { days }\end{array}$ & $\begin{array}{l}\square 1 \text { day } \\
\square 2 \text { days } \\
\square 3 \text { days } \\
\square \text { more than } 3 \text { days }\end{array}$ & $\begin{array}{l}\square 1 \text { day } \\
\square 2 \text { days } \\
\square 3 \text { days } \\
\square \text { more than } 3 \text { days }\end{array}$ & $\begin{array}{l}\square 1 \text { day } \\
\square 2 \text { days } \\
\square 3 \text { days } \\
\square \text { more than } 3 \text { days }\end{array}$ \\
\hline $\begin{array}{l}\text { How was the stool during } \\
\text { the illness? }\end{array}$ & $\begin{array}{l}\square \text { Watery } \\
\square \text { solid } \\
\square \text { bloody }\end{array}$ & $\begin{array}{l}\square \text { watery } \\
\square \text { solid } \\
\square \text { bloody }\end{array}$ & $\begin{array}{l}\square \text { watery } \\
\square \text { solid } \\
\square \text { bloody }\end{array}$ & $\begin{array}{l}\square \text { watery } \\
\square \text { solid } \\
\square \text { bloody }\end{array}$ \\
\hline $\begin{array}{l}\text { Did your child receive } \\
\text { treatment? }\end{array}$ & $\begin{array}{l}\square \text { yes } \\
\square \text { no }\end{array}$ & $\begin{array}{l}\square \text { yes } \\
\square \text { no }\end{array}$ & $\begin{array}{l}\square \text { yes } \\
\square \text { no }\end{array}$ & $\begin{array}{l}\square \text { yes } \\
\square \text { no }\end{array}$ \\
\hline
\end{tabular}

\section{$\square$ teething}

$\square$ fontanel

$\square$ parasites, worms

$\square$ germs, bacteria, virus 
1.7. What kind of treatment did the child receive? $\rightarrow$ ASK OPEN! MULTIPLE RESPONSES

If no diarrhoea incidence $\rightarrow$ What kind of treatment does the child normally get when it has diarrhoea?
$\square$ Traditional medicine/ healer
$\square$ Buy medicine from pharmacy / kiosk
$\square$ Visit the health centre / doctor
$\square$ Others

1.8. How much money did (do) you spend on the treatment of one diarrhoea case? Ksh

\section{What's your opinion? Questions}

2.1.

How old must a child be, that it can start with drinking untreated raw water?

Unadhani ni katika umri gain ambapo motto anaweza kunywa years

maji ya mfereji / kiosk ambayo haijatibiwa?

2.2.

Are your young children at a risk of getting diarrhoea? Je watoto wako wadogo wamo hatarini kupata ugonjwa wa kuhara?

Can young children get diarrhea from supernatural reasons like witchcraft or breaking norms?

Kuna uwezekano gani watoto wadogo kuambukizwa kuhara na njia zinginezo zisizo zakawaida kamavile uchawi, na itikadi?

How likely is it, that your young children will die, if they have severe diarrhoea?

Kuna uwezekano gani watoto wako wadogo watakufa wakiwa na mharo wa kupindukia?

Do your family members want you to treat raw water before drinking?

Je familia yako ingependelea utibu maji yako kabla ya kunywa?

How likely is it, that untreated raw water contains germs?

Kuna uwezekano gani kuwa maji ambayo haijatibiwa ina viini au vijidudu?

Can safe water be safely drunk, if you mix it with untreated raw water?

Unafikiria maji ambayo yametibiwa yanaweza kunywika yakiwa yamechanganywa na maji ambayo hayajatibiwa?

How dangerous is it, when young children have diarrhoea?

Kuna hatari kiasi gani watoto wadogo kuwa na ugonjwa wa kuhara?

Do germs in the drinking water cause diarrhea and sickness? Je viini vilivyo ndani ya maji ya kunywa vinaweza kusababisha kuhara na magonjwa megine?

How likely is it, that your young children get diarrhoea, when they drink untreated raw water?

Kuna uwezekano gani kuwa watoto wako wadogo watapata ugonjwa wa kuhara wakinywa maji ambayo hayajatibiwa?

\begin{tabular}{|c|c|c|c|c|}
\hline $\begin{array}{c}\text { No } \\
\text { Hapana }\end{array}$ & $\begin{array}{c}\text { Little } \\
\text { Kidogo }\end{array}$ & $\begin{array}{l}\text { Average } \\
\text { Kadri }\end{array}$ & $\begin{array}{l}\text { Rather } \\
\text { Pengine }\end{array}$ & $\begin{array}{l}\text { Very } \\
\text { Sana }\end{array}$ \\
\hline $\begin{array}{l}\text { Definitely } \\
\text { No }\end{array}$ & $\begin{array}{l}\text { Probably } \\
\text { No }\end{array}$ & Maybe & $\begin{array}{l}\text { Probably } \\
\text { Yes }\end{array}$ & $\begin{array}{c}\text { Definitely } \\
\text { Yes }\end{array}$ \\
\hline $\begin{array}{l}\text { Hapana } \\
\text { kabisa }\end{array}$ & $\begin{array}{l}\text { Pengine } \\
\text { hapana }\end{array}$ & Labda & Pengine & Ndio kabisa \\
\hline No & Little & Average & Rather & Very \\
\hline Hapana & Kidogo & Kadri & Pengine & Sana \\
\hline $\begin{array}{l}\text { Definitely } \\
\text { No }\end{array}$ & $\begin{array}{l}\text { Probably } \\
\text { No }\end{array}$ & Maybe & $\begin{array}{l}\text { Probably } \\
\text { Yes }\end{array}$ & $\begin{array}{c}\text { Definitely } \\
\text { Yes }\end{array}$ \\
\hline $\begin{array}{l}\text { Hapana } \\
\text { kabisa }\end{array}$ & $\begin{array}{l}\text { Pengine } \\
\text { hapana }\end{array}$ & Labda & Pengine & Ndio kabisa \\
\hline No & Little & Average & Rather & Very \\
\hline Hapana & Kidogo & Kadri & Pengine & Sana \\
\hline $\begin{array}{l}\text { Definitely } \\
\text { No }\end{array}$ & $\begin{array}{l}\text { Probably } \\
\text { No }\end{array}$ & Maybe & $\begin{array}{l}\text { Probably } \\
\text { Yes }\end{array}$ & $\begin{array}{c}\text { Definitely } \\
\text { Yes }\end{array}$ \\
\hline $\begin{array}{l}\text { Hapana } \\
\text { kabisa }\end{array}$ & $\begin{array}{l}\text { Pengine } \\
\text { hapana }\end{array}$ & Labda & Pengine & Ndio kabisa \\
\hline No & Little & Average & Rather & Very \\
\hline Hapana & Kidogo & Kadri & Pengine & Sana \\
\hline $\begin{array}{l}\text { Definitely } \\
\text { No }\end{array}$ & $\begin{array}{l}\text { Probably } \\
\text { No }\end{array}$ & Maybe & $\begin{array}{l}\text { Probably } \\
\text { Yes }\end{array}$ & $\begin{array}{c}\text { Definitely } \\
\text { Yes }\end{array}$ \\
\hline $\begin{array}{c}\text { Hapana } \\
\text { kabisa }\end{array}$ & $\begin{array}{c}\text { Pengine } \\
\text { hapana }\end{array}$ & Labda & Pengine & Ndio kabisa \\
\hline No & Little & Average & Rather & Very \\
\hline Hapana & Kidogo & Kadri & Pengine & Sana \\
\hline
\end{tabular}


2.3. How often do the children below 5 years eat fruits?

$\square \quad$ several times each day

$\square$ once a day

$\square \quad$ two or three times a week $\square$ once a week

$\square$ once every two weeks

$\square$ once a month never

2.4. How do you prepare fruits for eating? $\rightarrow$ ASK OPEN, MULTIPLE RESPONSES

$\square$ washing fruits mentioned
$\square$ nothing of these mentioned

$\square$ peeling mentioned

$\square$ washing hands mentioned

2.5. How often do the children below 5 years eat uncooked raw vegetables e.g. kachumbari (vegeta. salad)?

$\square \quad$ several times each day

$\square$ once a day

$\square \quad$ two or three times a week $\square$ once a week

$\square$ once every two weeks

$\square$ once a month never

\section{Consumption of liquids}

3.1. What kind of drinks do your children below 5 years consume?

$\rightarrow$ ASK OPEN! MULTIPLE RESPONSES

3.2. How much of each liquid do your children below 5 years drink each day?

$\rightarrow$ NAME THE CHILD, USE CUP!

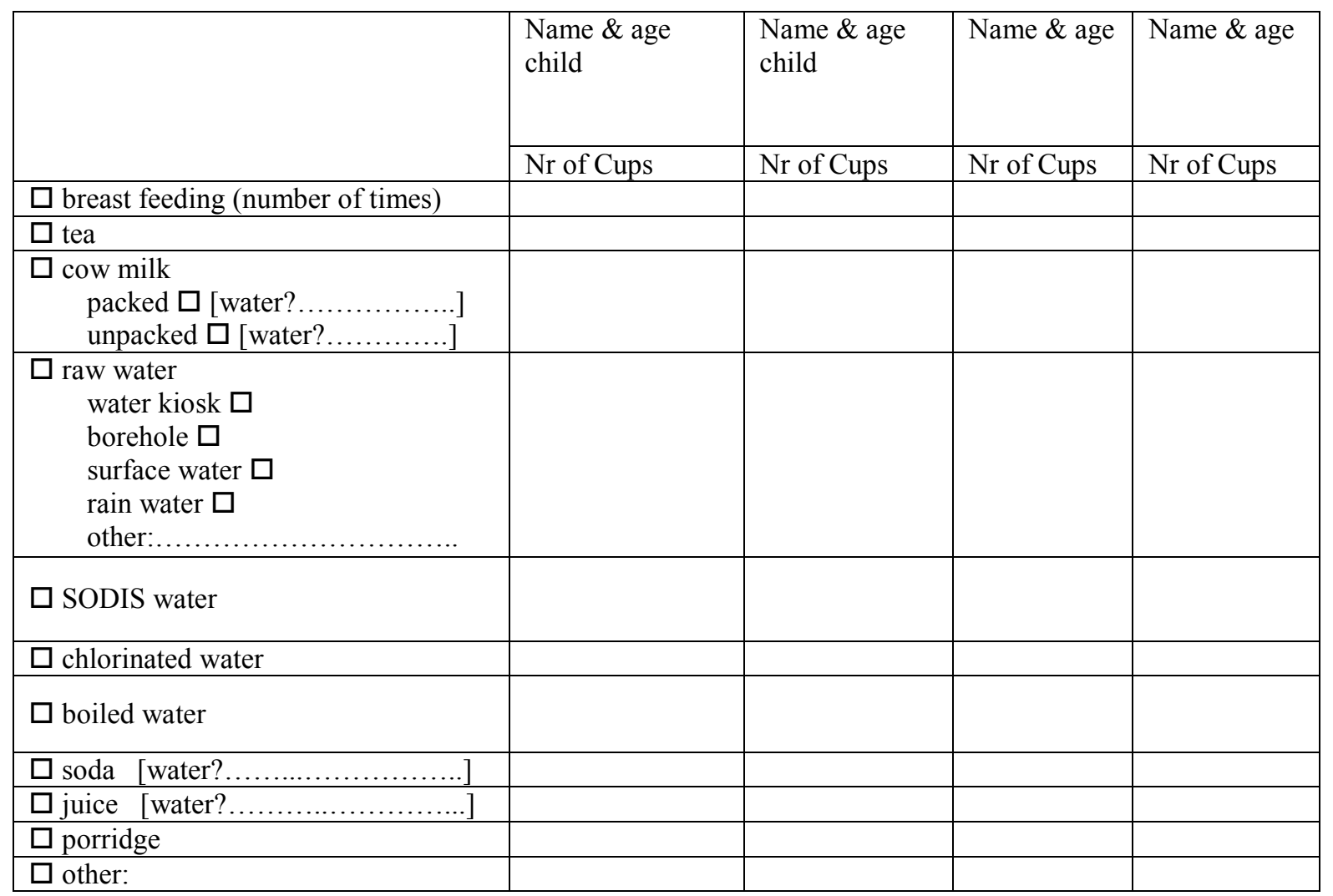


3.3. How many bottles of SODIS water do you treat each day?

3.4. How many people in your household drink SODIS water (children below 16 years included)?

3.5. Non-Users: Do you know SODIS? Have you heard of it?

SODIS is a water treating method for which you need a PET-bottle and sunlight.

$\square$ Yes, I have heard of it, but I don't really know

$\square$ Yes, I know it from friends, neighbours

$\square$ Yes, I know it from workshop / promotion

$\square$ No $\rightarrow$ GO TO 5. GENERAL HYGIENE AND SANITATION

\subsection{Questions about SODIS}

\begin{tabular}{|c|c|c|c|c|c|c|}
\hline $\begin{array}{l}\text { Do you know how to treat and get SODIS water? } \\
\text { Je unaelewa vyema jinsi ya kutayarisha maji ya } \\
\text { SODIS? }\end{array}$ & $\begin{array}{l}\text { Definitely No } \\
\text { Hapana kabisa }\end{array}$ & $\begin{array}{l}\text { Probably } \\
\text { No } \\
\text { Pengine } \\
\text { hapana }\end{array}$ & Labda & $\begin{array}{l}\text { Probably } \\
\text { Yes } \\
\text { Pengine }\end{array}$ & $\begin{array}{l}\text { Definitely } \\
\text { Yes } \\
\text { Ndio kabisa }\end{array}$ & \\
\hline $\begin{array}{l}\text { oes the production of SODIS water need a lot of time? } \\
\text { unafikiria kutayarisha maji ya SODIS unahitaji } \\
\text { uda mrefu? }\end{array}$ & $\mid \begin{array}{l}\text { Definitely No } \\
\text { Hapana kabisa }\end{array}$ & $\begin{array}{l}\text { Probably } \\
\text { No } \\
\text { Pengine } \\
\text { hapana } \\
\end{array}$ & Maybe & $\begin{array}{l}\text { Probably } \\
\text { Yes } \\
\text { Pengine }\end{array}$ & $\begin{array}{l}\text { Definitely } \\
\text { Yes } \\
\text { Ndio kabisa }\end{array}$ & $\begin{array}{l}n^{\prime} t \\
\text { ow }\end{array}$ \\
\hline $\begin{array}{l}\text { S? } \\
\text { DIS? }\end{array}$ & $\begin{array}{l}\text { Definitely No } \\
\text { Hapana kabisa }\end{array}$ & \begin{tabular}{|l|} 
Probably \\
No \\
Pengine \\
hapana \\
\end{tabular} & & $\begin{array}{l}\text { Probably } \\
\text { Yes } \\
\text { Pengine }\end{array}$ & $\begin{array}{l}\text { Definitely } \\
\text { Yes } \\
\text { Ndio kabisa }\end{array}$ & \\
\hline $\begin{array}{l}\text { ng children get less diarrhoea, if they drink Sodis } \\
\text { dhani kuwa ugonjwa wa kuhara utapunguwa } \\
\text { wadogo wakikunywa maji ya SODIS? }\end{array}$ & $\begin{array}{l}\text { Definitely No } \\
\text { Hapana kabisa }\end{array}$ & \begin{tabular}{|l|} 
Probably \\
No \\
Pengine \\
hapana \\
\end{tabular} & Labda & $\begin{array}{l}\text { Probably } \\
\text { Yes } \\
\text { Pengine }\end{array}$ & $\begin{array}{l}\text { Definitely } \\
\text { Yes } \\
\text { Ndio kabisa }\end{array}$ & $\begin{array}{l}\text { Don't } \\
\text { Know }\end{array}$ \\
\hline $\begin{array}{l}\text { ttles for preparing enough } \\
\text { a ya PET zakutosha } \\
\text { ? }\end{array}$ & $\begin{array}{l}\text { Definitely No } \\
\text { Hapana kabisa }\end{array}$ & $\begin{array}{l}\text { Probably } \\
\text { No } \\
\text { Pengine } \\
\text { hapana } \\
\end{array}$ & Labda & $\begin{array}{l}\text { Probably } \\
\text { Yes } \\
\text { Pengine }\end{array}$ & $\begin{array}{l}\text { Definitely } \\
\text { Yes } \\
\text { Ndio kabisa }\end{array}$ & $\begin{array}{l}\text { Don't } \\
\text { Know }\end{array}$ \\
\hline $\begin{array}{l}\text { gularly? } \\
\text { DIS }\end{array}$ & $\begin{array}{l}\text { Definitely No } \\
\text { Hapana kabisa }\end{array}$ & $\begin{array}{l}\text { Probably } \\
\text { No } \\
\text { Pengine } \\
\text { hapana } \\
\end{array}$ & Labda & \begin{tabular}{|c|} 
Probably \\
Yes \\
Pengine
\end{tabular} & $\begin{array}{l}\text { Definitely } \\
\text { Yes } \\
\text { Ndio kabisa }\end{array}$ & $\begin{array}{l}\text { Don't } \\
\text { Know }\end{array}$ \\
\hline $\begin{array}{l}\text { Does SODIS make } \\
\text { Je SODIS huyage } \\
\text { kunywa baada ya }\end{array}$ & $\begin{array}{l}\text { Definitely No } \\
\text { Hapana kabisa }\end{array}$ & $\begin{array}{l}\text { Probably } \\
\text { No } \\
\text { Pengine } \\
\text { hapana } \\
\end{array}$ & $\begin{array}{l}\text { Maybe } \\
\text { Labda }\end{array}$ & \begin{tabular}{|c|c|}
$\begin{array}{c}\text { Probably } \\
\text { Yes }\end{array}$ \\
Pengine
\end{tabular} & \begin{tabular}{|c|}
$\begin{array}{c}\text { Definitely } \\
\text { Yes }\end{array}$ \\
Ndio kabisa \\
\end{tabular} & $\begin{array}{l}\text { Don't } \\
\text { Know }\end{array}$ \\
\hline $\begin{array}{l}\text { Can SODIS water be c } \\
\text { Je unafikiria maji ya } \\
\text { baada ya kutibiwa? }\end{array}$ & $\begin{array}{l}\text { Definitely No } \\
\text { Hapana kabisa }\end{array}$ & $\begin{array}{l}\text { Probably } \\
\text { No } \\
\text { Pengine } \\
\text { hapana } \\
\end{array}$ & $\begin{array}{l}\text { Maybe } \\
\text { Labda }\end{array}$ & $\begin{array}{l}\text { Probably } \\
\text { Yes } \\
\text { Pengine } \\
\end{array}$ & \begin{tabular}{|l} 
Definitely \\
Yes \\
Ndio kabisa \\
\end{tabular} & $\begin{array}{l}\text { Don't } \\
\text { Know }\end{array}$ \\
\hline $\begin{array}{l}\text { oes water shortage make it difficult for you to produce } \\
\text { ODIS water regularly? } \\
\text { unafikiri ukosefu / uhaba wa maji waweza } \\
\text { uchangia kutotayarisha maji yako ya SODIS } \\
\text { lawakati? }\end{array}$ & $\begin{array}{l}\text { Definitely No } \\
\text { Hapana kabisa }\end{array}$ & $\begin{array}{l}\text { Probably } \\
\text { No } \\
\text { Pengine } \\
\text { hapana }\end{array}$ & Maybe & $\begin{array}{l}\text { Probably } \\
\text { Yes } \\
\text { Pengine }\end{array}$ & $\begin{array}{l}\text { Definitely } \\
\text { Yes } \\
\text { Ndio kabisa }\end{array}$ & $\begin{array}{l}\text { Don't } \\
\text { Know }\end{array}$ \\
\hline $\begin{array}{l}\text { How often is weather a problem for producing SODIS } \\
\text { water? } \\
\text { Je mara kwa mara hali ya anga huwa tatizo kwa }\end{array}$ & $\begin{array}{l}\text { Never } \\
\text { hapana }\end{array}$ & $\begin{array}{l}\text { Rarely } \\
\text { kidogo }\end{array}$ & $\begin{array}{c}\text { Some- } \\
\text { times } \\
\text { saa } \\
\text { zingine } \\
\end{array}$ & $\begin{array}{c}\text { Mostly } \\
\text { mara } \\
\text { nyingi }\end{array}$ & \begin{tabular}{|c} 
Always \\
kila wakati
\end{tabular} & $\begin{array}{l}\text { Don't } \\
\text { Know }\end{array}$ \\
\hline $\begin{array}{l}\text { ow often are you too busy to treat SODIS water? } \\
\text { mara kwa mara wewe huwa na shuguli nyingi } \\
\text { nbazo hukuzuia kutayarisha maji ya SODIS? }\end{array}$ & $\begin{array}{l}\text { Never } \\
\text { hapana }\end{array}$ & $\begin{array}{l}\text { Rarely } \\
\text { kidogo }\end{array}$ & $\begin{array}{c}\text { Some- } \\
\text { times } \\
\text { saa } \\
\text { zingine } \\
\end{array}$ & $\begin{array}{c}\text { Mostly } \\
\text { mara } \\
\text { nyingi }\end{array}$ & \begin{tabular}{|c} 
Always \\
kila wakati
\end{tabular} & $\begin{array}{l}\text { Don't } \\
\text { Know }\end{array}$ \\
\hline
\end{tabular}




\begin{tabular}{|c|c|c|c|c|c|c|}
\hline $\begin{array}{l}\text { How likely is it, that SODIS kills the germs in raw } \\
\text { water? } \\
\text { Kuna uwezekano gani kuwa SODIS huua viini katika } \\
\text { maji ambayo hayajatibiwa? }\end{array}$ & $\begin{array}{c}\text { No } \\
\text { Hapana }\end{array}$ & $\begin{array}{l}\text { Little } \\
\text { Kidogo }\end{array}$ & $\begin{array}{l}\text { Average } \\
\text { Kadri }\end{array}$ & $\begin{array}{l}\text { Rather } \\
\text { Pengine }\end{array}$ & $\begin{array}{l}\text { Very } \\
\text { Sana }\end{array}$ & $\begin{array}{l}\text { Don't } \\
\text { Know }\end{array}$ \\
\hline $\begin{array}{l}\text { How often do you just forget to produce SODIS water? } \\
\text { Mara kwa mara wewe husahau kutayarisha maji ya } \\
\text { SODIS? }\end{array}$ & $\begin{array}{l}\text { Never } \\
\text { hapana }\end{array}$ & $\begin{array}{l}\text { Rarely } \\
\text { kidogo }\end{array}$ & \begin{tabular}{|c|}
$\begin{array}{c}\text { Some- } \\
\text { times } \\
\text { saa } \\
\text { zingine }\end{array}$ \\
\end{tabular} & $\begin{array}{c}\text { Mostly } \\
\text { mara } \\
\text { nyingi }\end{array}$ & $\begin{array}{c}\text { Always } \\
\text { kila wakati }\end{array}$ & $\begin{array}{l}\text { Don't } \\
\text { Know }\end{array}$ \\
\hline
\end{tabular}

\subsection{How is Sodis water produced? $\rightarrow$ ASK OPEN! LET RESPONDENT EXPLAIN}

The knowledge is...
$\square$ very good
$\square \operatorname{good}$
- clean PET-bottle
$-3 / 4$ water, shake
- sun exposition
- 8 hours / 1 day
- cloudy $\rightarrow 2$ days
- sun kills germs
- drink out of bottle
$\square$ ok

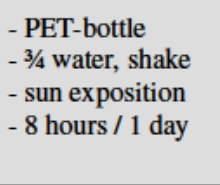
$\square$ poor

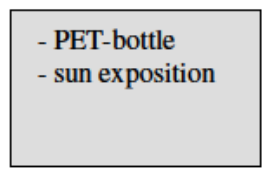
$\square$ very poor
I don't know

4.3. Could you explain how SODIS treats water, how it works? $\rightarrow$ ASK OPEN! LET RESP. EXPLAIN

The knowledge is...

\begin{tabular}{l|}
\hline good \\
\hline - sun kills germs in the \\
water \\
- heat and radiation of \\
sun \\
- needs a 8 hours \\
\hline
\end{tabular}
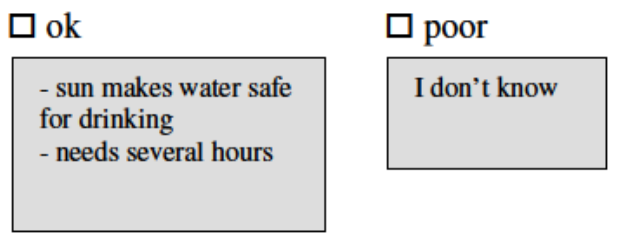

\section{General hygiene and sanitation}

5.1. What kind of facilities do the people of your household use for toilet? $\rightarrow$ ASK OPEN! MULTIPLE RESP.
$\square$ Public toilet
$\square \quad$ Plastic bag
$\square$ Open ground
$\square$ Private toilet
$\square$ Bucket
$\square$ Other:

5.2. How many times do your children below 5 years wash their hands per day? $\rightarrow$ ASK OPEN!

$\square$ never times

5.3. Do the children below 5 years use soap for hand washing? If yes how often?
$\square$ never
$\square$ rarely
sometimes
$\square$ mostly
$\square$ always

5.4. When do your children below 5 years wash their hands? $\rightarrow$ ASK OPEN! MULTIPLE RESONSES

$\square \quad$ before eating
$\square \quad$ after eating
$\square \quad$ before cooking
$\square$ after toilet
$\square$ before sleeping
$\square$ after sleeping

when hands are dirty

$\square$ when bathing

other: 


\section{Observation of the interviewer:}

Is soap in the household available?
$\square$ No
$\square$ Yes

Is the water storage in the household covered?
$\square$ No
$\square$ Yes
I could not see $\square$

How many bottles of SODIS are on the roof?

How many PET-bottles are in the household?

How is the condition of the PET-bottles?

\begin{tabular}{|l|}
$\square$ good \\
\hline - very clean \\
- transparent \\
- new looking \\
\hline
\end{tabular}

\begin{tabular}{l}
$\square$ ok \\
- still good but used \\
for a while \\
\hline
\end{tabular}

\begin{tabular}{|l|}
\hline poor \\
\hline - dirty \\
- not transparent \\
- very old looking \\
\hline
\end{tabular}

What is the volume of the PET-bottles?

$\square$ half litre $\quad \square$ one litre $\quad \square 1.5$ litre $\quad \square 2$ litre $\quad \square 3$ litre

Hygiene of the household

\begin{tabular}{|l|}
\hline \\
\hline very clean \\
\hline - clean, not dirty \\
- food is covered \\
- no flies \\
- no rubbish \\
\hline
\end{tabular}

\begin{tabular}{|l|}
$\square$ medium clean \\
\begin{tabular}{|l|}
\hline - little dirty \\
- most food covered \\
- few flies \\
- few rubbish \\
\hline
\end{tabular} \\
\hline
\end{tabular}

\begin{tabular}{|l|}
\hline dirty \\
\hline - dirty \\
- food uncovered \\
- some flies \\
- some rubbish \\
\hline
\end{tabular}

\begin{tabular}{|l|}
\hline \\
\hline very dirty \\
\hline - very dirty \\
- food uncovered \\
- a lot of flies \\
- a lot of rubbish \\
\hline
\end{tabular}

Cleanliness of hands of respondent
$\square$ clean
$\square$ dirty

Cleanliness of hands of young children around

$\rightarrow$ MAKE SURE CHILDREN BELONG TO HOUSEHOLD
$\square$ clean $\quad \square$ dirty

Cleanliness of surroundings of household
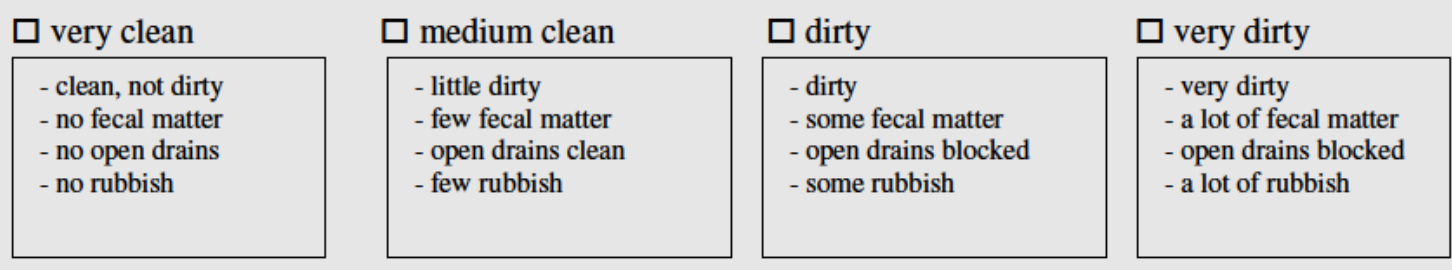

Welfare of the household

$\square$ very poor
\begin{tabular}{|l|}
\hline - very few properties \\
- very few and old \\
furniture \\
\hline
\end{tabular}

\begin{tabular}{l}
$\square$ rather poor \\
$\begin{array}{l}\text { - few properties } \\
\text { - few and medium old } \\
\text { furniture }\end{array}$ \\
\hline
\end{tabular}

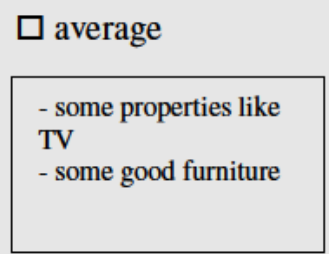

$\square$ wealthy

- luxury properties like
TV, Computer
- new and good
furniture

I could not really see $\square$ 